\title{
Differences of sodium consumption pattern hypertension sufferer in coastal and highland communities in Wakatobi islands
}

La Ode Alifariki ${ }^{1}$ Tukatman Tukatman², Bangu Bangu², Heriviyatno Julika Siagian²*

DOI. 10.21931/RB/2021.01.02.12

Abstract: Available data indicate that food sodium (such as salt) is directly related to blood pressure (BP). The research aims to look at the different sodium consumption patterns of hypertension sufferers in two different coastal areas and highland areas in the Wakatobi Islands. The type of research is observational analytic research using a cross-sectional design. This study has been carried out in the District of Wangi-Wangi, especially in the MolaSamaturu villages and Waginopo Village in October 2019. The number of research samples is 100 people (50 respondents in Mola Samaturu Village and 50 people in Waginopo Village). The results showed the differences between sodium consumption patterns in hypertensive sufferers in Mola Samaturu Village and Waginopo Village with a $p$-value $=0,000<\mathrm{a} 0.05$. Sodium consumption patterns in coastal communities are higher than in highlands community.

Key words: Hypertension, sodium consumption pattern, Wakatobi islands.

\section{Introduction}

Hypertension is a significant risk factor for cardiovascular and cerebral vascular disease, also kidney failure. It is known that the amount of salt intake in meals plays a role in the pathogenesis of primary hypertension ${ }^{1-3}$. Increased sensitivity of blood pressure toward excess sodium affects $50 \%$ of patients with primary hypertension ${ }^{4,5}$. Salt dietary intake causes enhancement of blood pressure associated with kidney and cardiovascular diseases, including left ventricular hypertrophy and microalbuminuria ${ }^{6}$.

Sodium is the most cation in an extracellular fluid where $35-40 \%$ (60 mmol per $\mathrm{kg}$ of body weight) is in the skeleton, and a small portion (about 10-14 mmol / L) is in the intracellular fluid7. Under normal circumstances, sodium excretion in the kidneys is regulated to maintain a balance between intake and output, with extracellular fluid volume remains stable ${ }^{8}$. More than $90 \%$ of the extracellular fluid's osmotic pressure is determined by salt, specifically in sodium chloride $(\mathrm{NaCl})$ and sodium bicarbonate ( $\mathrm{NaHCO}$ ), thereby changing the osmotic pressure in the extracellular fluid represents changing sodium concentration?.

Increased sodium intake causes fluid retention of the body, which increases blood volume by pulling intra-cellular fluid into extracellular so that the heart should pump forcefully to drive large volumes of blood through narrowing of the intravascular space, which results in hypertension ${ }^{10,11}$. This was proven in a study conducted by Abdurrachim, Hariyawati, and Suryani ${ }^{12}$ that there was a significant relationship between sodium intake with blood pressure in the elderly at TresnaWerdhanursing Home and BinaLaras Budi Luhur nursing home, Banjarbaru City.

Blood pressure is the bloodstream pressure in blood vessels and circulates in all tissues of the human body ${ }^{13,14}$. Blood pressure consists of 2 parts of systolic pressure and diastolic pressure ${ }^{15,16}$. Systolic blood pressure is defined as the pressure during heart contractions, while diastolic blood pressure is defined as blood pressure when the heart relaxes ${ }^{14}$.

The sodium content in foods dramatically varies and depends on the food source (e.g., animal foods source naturally contain more sodium) and the level of change that food itself goes through. Foods that are naturally low in sodium are fruits, vegetables, oils, and cereals, with the contents range from 20 mg up to $100 \mathrm{~g}^{7}$.

The Food and Agriculture Organization (FAO) and WHO recommends that the amount of salt consumption in the community is less than 5 gram a day because of the adverse effects of excessive salt consumption on health, especially on blood pressure and cardiovascular disease ${ }^{4,17}$. Based on data from National Basic Health Research in 2013, it was found that the prevalence of risky food consumption patterns, especially salty foods, was $26.2 \%$, and Southeast Sulawesi was $11.5 \%{ }^{18}$.

Geographically, the Wangi-Wangi Islands' position is surrounded by the sea of Banda, where most of the people in the community earn a livelihood as seaweed farmers and fishers even though there are some villages that quite far from the coast with livelihoods as land farmers. This geographical position gives a plus and minus effect on the health of the Wangi-Wangi community, especially those living in coastal areas exposed to high salt or sodium consumption patterns.

According to Bustan, more people living in urban areas suffer from hypertension than people living in villages; furthermore, based on the geographical location where coastal areas have more hypertension than highland areas ${ }^{19}$. Research conducted by Setiawati on the coast of Manado Tua Island obtained a significant relationship between sodium intake and the incidence of hypertension ${ }^{20}$.

Based on the phenomenon, this study aims to determine differences in sodium consumption patterns of hypertensive patients in coastal and highland communities in the Wakatobi Islands.

\section{Methods}

The type of study is observational analytic research using a cross-sectional design. This research has been conducted in the District of Wangi-Wangi, specifically atMolaSamaturuvillage and Waginopo Village, in October 2019. The study population comprises all people with hypertension who live in MolaSamaturu Village (124 people) and Waginopo Village (116 people), with 240 people in October 2019. The number 
of research samples was 100 people $(50$ respondents in MolaSamaturu Village and 50 people in Waginopo Village). The blood pressure variable is obtained by measuring using a blood pressure meter with hypertension criteria for hypertension sufferers is $140 / 90 \mathrm{mmHg}$ (first-degree hypertension, second-degree hypertension, and third-degree hypertension). The sodium consumption pattern variable is obtained by measuring the consumption pattern using the Food Frequency Questionnaire (FFQ) then analyzed using a Nutri survey with a safe sodium consumption pattern standard ( $<2000$ mg/day). The statistical test uses an independent t-test with a value of $a=0.05$.

\section{Results}

Table 1 shows respondents' characteristics with hypertension based on age range mostly in the MolaSamaturu village as 30\% with age range $30-35$ years old. In the Waginopo village, mostly in the age range $42-47$ years old is $44 \%$. By gender characteristics, mostly in MolaSamaturu Village with a percentage of $46 \%$ men and Waginopo Village the most were $44 \%$ men. By type of occupation, in MolaSamaturu village, $62 \%$ of respondents are fishermen, and Waginopo Village, most of the respondents, are farmers as much as 50\%. Characteristics of respondents based on $\mathrm{BMI}$ show the most respondents in the MolaSamaturu village is in normal BMI (18.5-25.0) as much as

\begin{tabular}{|c|c|c|c|c|}
\hline \multirow[t]{2}{*}{ Characteristics } & \multicolumn{2}{|c|}{ MolaSamaturu Village } & \multicolumn{2}{|c|}{ Waginopo Village } \\
\hline & Frequency(n) & Percentage (\%) & Frequency (n) & Percentage $(\%)$ \\
\hline \multicolumn{5}{|l|}{ Range of Age } \\
\hline $24-29$ & 12 & 24 & 4 & 8 \\
\hline $30-35$ & 15 & 30 & 2 & 4 \\
\hline $36-41$ & 8 & 16 & 10 & 20 \\
\hline $42-47$ & 11 & 22 & 22 & 44 \\
\hline $48-53$ & 4 & 8 & 12 & 24 \\
\hline \multicolumn{5}{|l|}{ Gender } \\
\hline Male & 23 & 46 & 15 & 30 \\
\hline Female & 22 & 44 & 35 & 70 \\
\hline \multicolumn{5}{|l|}{ Occupation } \\
\hline Farmer & 0 & 0 & 25 & 50 \\
\hline Housewife & 13 & 26 & 10 & 20 \\
\hline Fisherman & 31 & 62 & 2 & 4 \\
\hline Laborer & 4 & 8 & 10 & 20 \\
\hline $\begin{array}{l}\text { Goverument } \\
\text { Employees }\end{array}$ & 2 & 4 & 3 & 6 \\
\hline \multicolumn{5}{|l|}{ BMI } \\
\hline Thin $(17,0-18,4)$ & 7 & 14 & 3 & 6 \\
\hline Normal $(18,5-25,0)$ & 37 & 74 & 37 & 74 \\
\hline Obesity $(25,1-27,0)$ & 10 & 20 & 12 & 24 \\
\hline
\end{tabular}


$74 \%$, either in the Waginopo village, most of the respondents is in the normal BMI with the percentage of $74 \%$.

Based on table 2, respondents' characteristics in the category of hypertension in the MolaSamaturu village mostly in the stage I category with percentage is $50 \%$, the same in Waginopo village that mostly is in the stage I as many as $66 \%$. For the sodium consumption pattern variable, MolaSamaturu village with $68 \%$ is in $\geq 2000 \mathrm{mg} /$ day category, while in Waginopo village mostly in < $2000 \mathrm{mg} /$ day category with $76 \%$ of respondents (Table 2 ).

Table 3 shows that the mean systolic and diastolic blood pressure values of respondents in Mola Samaturu were higher than respondents in Waginopo Village, as well as sodium consumption, higher in Mola Samaturu Village, higher than respondents in Waginopo Village.

Table 4 shows a difference between Sodium consumption pattern hypertension sufferers in MolaSamaturu village and Waginopo village with $\mathrm{p}$ value $=0.000<\mathrm{a} 0.05$ (table 4).

\section{Discussion}

Sample testing is based on the relationship between hypertension as a dependent variable with seafood consumption as an independent variable along with other risk factors causing hypertension, such as age, gender, alcohol consumption, smoking, history of DM, family history of DM, history of dyslipidemia, and history dyslipidemia in families not examined in this study.

This research shows that hypertension is more in coastal areas (MolaSamaturu Village) compared to highland areas (Waginopo Village). Sodium is a mineral found in the body and many foods source. Sodium is an essential nutrient for maintaining blood volume, regulating water balance in cells, and maintaining nerve function. The kidney controls sodium balance by increasing or decreasing the excretion of sodium in the urine. Another theory states that kidney disorders cannot correctly excrete sodium ( $\mathrm{Na}$ ) in average amounts; the conse-

\begin{tabular}{|l|c|c|c|c|}
\hline \multicolumn{1}{|c|}{ Characteristics } & \multicolumn{2}{|c|}{ MolaSamaturu village } & \multicolumn{2}{c|}{ Waginopo village } \\
\hline Category of & Frequency & Percentage & Frequency & Percentage \\
\hline Hypertension & (n) & $(\%)$ & (n) & $(\%)$ \\
\hline Hypertension stage I & 25 & 50 & 33 & 66 \\
\hline Hypertension stage II & 13 & 26 & 14 & 28 \\
\hline Hypertension stage III & 12 & 24 & 3 & 6 \\
\hline Sodium Consumption & & & & \\
\hline Pattem & & & & \\
\hline$\geq 2000 \mathrm{mg}$ day & 34 & 68 & 12 & 24 \\
\hline$<2000 \mathrm{mg}$ day & 16 & 32 & 38 & 76 \\
\hline
\end{tabular}

Table 2. Distribution of variables .

\begin{tabular}{|l|c|c|c|c|}
\hline \multirow{2}{*}{ Variable } & \multicolumn{2}{|c|}{ Mola Samaturu village } & \multicolumn{2}{c|}{ Waginopo village } \\
\cline { 2 - 5 } & mean & min-max & mean & min-max \\
\hline Diastolic blood pressure & 96.6 & $80-120$ & 95.8 & $80-120$ \\
Systolic blood pressure & 163.5 & $140-210$ & 156.0 & $140-200$ \\
\hline Sodium Consumption Pattem & 3020.08 & $1256-9887$ & 1983.98 & $897-7600$ \\
\hline
\end{tabular}

Table 3. Distribution of mean score, minimum-maximum blood pressure, and sodium consumption pattern hypertension sufferer.

\begin{tabular}{|l|c|c|c|}
\hline Sodium Consumption Pattern & n & Mean Rank & p value \\
\hline$\geq 2000 \mathrm{mg} /$ day & 46 & 37.8 & 0.000 \\
\hline$<2000 \mathrm{mg} /$ day & 54 & 61.3 & \\
\hline
\end{tabular}

Table 4. Distribution of mean score, minimum-maximum blood pressure, and sodium consumption pattern hypertension sufferer. 


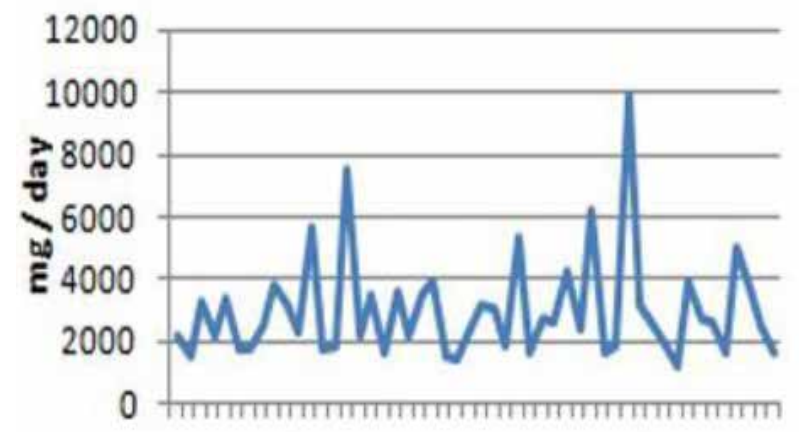

- Sodium Consumption Pattern
Figure 1. Sodium consumption pattern in Molasamaturu Village.

\section{9}

Figure 2. Sodium consumption pattern in WaginopoVillage.

\section{responden $(n=50)$}

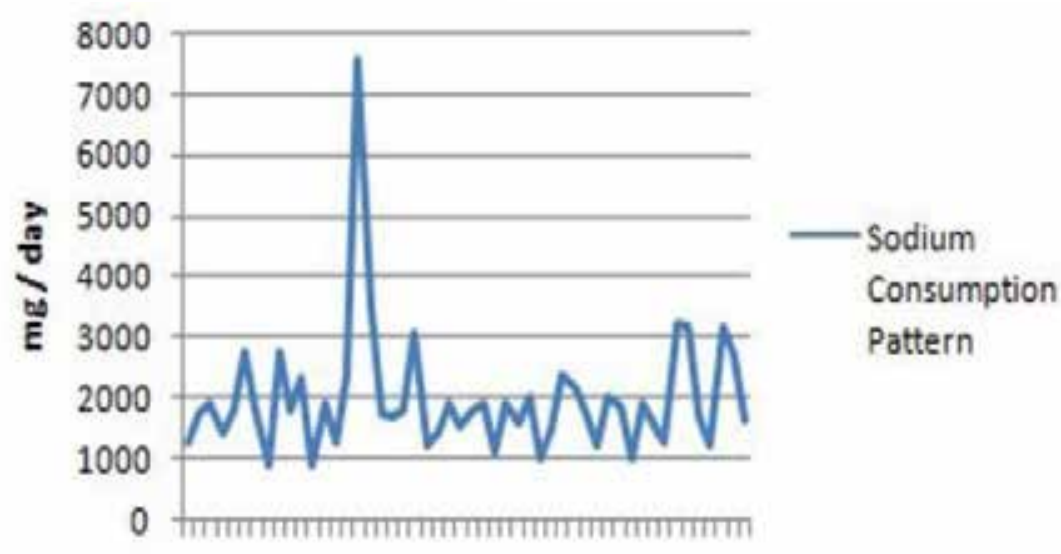

15913172125293337414549

responden $(n=50)$

quences are sodium ( $\mathrm{Na}$ ) in intravascular volume increase so that hypertension occurs ${ }^{21}$

The distribution of stage II and III hypertension sufferers shows that higher in coastal communities than in the highlands; this can be attributed to the excessive sodium consumption behavior found in seafood. The recommended daily sodium consumption is around $2400 \mathrm{mg}$, which can be achieved from salt around 2000 mg while another $400 \mathrm{mg}$ is found in the food consumed ${ }^{22}$

The food consumption pattern of highland communities, especially in the Waginopo area, shows the same thing with coastal communities in frequency. However, there are significant differences in the types of food that characterize coastal communities, such as shellfish, crabs, and others that contain high sodium. This is in line with previous research, which states that the consumption patterns of coastal communities have a frequency of eating 3 times a day with staple foods, namely rice, animal consumption patterns are relatively high, especially seafood and fish ponds, while the pattern of fruit consumption is still relatively low frequency 0 in a day with a percentage of $75 \%^{23}$.

In 1904, Ambard and Beaujard revealed salt intake correlates to BP as the first study on hypertension diet conducted on 6 patients with hypertension for 3 weeks using three types of salt and protein. The amount of salt in the body is measured by salt in food and urine per day. The amount of salt in the intake is small, the patient will experience a negative sodium balance, and blood pressure decreases. Otherwise, if the amount of salt in the intake is high, the amount of salt will be excreted a little so that sodium balance is achieved, and blood pressure will increase even though the amount of protein intake is small. Based on the result, the conclusion was the salt affects blood pressure. They were conducting the restriction on salt intake and success to reduce blood pressure ${ }^{24}$

This study's analysis results indicate that the highest sodium intake is in the coastal area, where sodium intake is excessive with a percentage of $68 \%$. In contrast, in the highlands region, the highest sodium intake category is the sodium intake category, with a percentage of $76 \%$. Factors that influence the high consumption of salt or sodium in coastal communities in the MolaSamaturu village are raw eating habits of shellfish, sea urchins, and salted fish. From the survey results, people in coastal areas consume high sodium foods daily, especially salted fish in hurricane season becomes the primary alternative for a food source in the coastal community. Another case is the community in Waginopo Village, which rarely consumes seafood from shellfish and salted fish. Some respondents even said that dried fish was not salted but only dried and then processed and consumed.

Research on the relationship of seafood with the incidence of hypertension has been done by Masengi et $a{ }^{2}{ }^{25}$, which states a significant relationship between seafood consumption with the incidence of hypertension ( $p=0.001$ ).

Statistically, there was a significant difference $(p=0.00)$ for sodium intake in coastal areas and highlands areas where sodium intake was higher in coastal areas than in the highland 
area. This study is in line with Sundari et ${ }^{2}{ }^{26}{ }^{26}$, where sodium intake significantly affects essential hypertension, p-value-in line with research Rusliafa et al. ${ }^{27}$ states that there are differences in hypertension incidence in coastal and highland areas, namely eating pattern (sodium intake $\mathrm{p}=0.026$ ).

Several studies have been conducted in some areas worldwide regarding daily salt intake related to blood pressure. A survey of salt intake in the newfound land area revealed the differences between the center of the island (inland) and the coastal community, where the typical salt intake is varying between 6.7 and $7.3 \mathrm{~g} /$ day compared to 8.4 and $8.8 \mathrm{~g} /$ day $^{28}$. Parallel changes in the incidence of hypertension lead to differences in salt intake in several regions. The incidence of hypertension in the inland community was $15 \%$, aged between 55 to 75 years old, lower than the coastal community with a percentage around $27 \%$. Similar results were found among the Solomon Islanders ${ }^{29}$. In those tribes, had a salt intake below $2 \mathrm{~g} /$ day, only $1 \%$ of the population having raised in BP which lived away from the coast. About 3\% of the Inland community population experienced elevating BP with salt intakes around 3 and $8 \mathrm{~g} /$ day. While people who lived on the coastal area had a salt intake between 9 to $15 \mathrm{~g} /$ day, indicating an increase of $\mathrm{BP}$ around $8 \%$ of the population. Migratory, in his study, found a relationship between daily salt intake and BP.The similarities in the results of this study are probably caused by the same characteristics of coastal and mountainous communities in consuming their daily food.

\section{Conclusions}

There is a difference between sodium consumption patterns in hypertensive sufferers in Mola Samaturu Village and Waginopo Village with a $p$-value $=0,000<a$ 0.05. Sodium consumption patterns in coastal communities are higher than in highlands community. This is due to the ease of getting foods that contain high sodium compared to highland areas. Further studies may find out the possibility of food modification that can reduce sodium levels, especially in coastal areas.

\section{Acknowledgment}

The author would like to thank the parties who have contributed to the implementation of this research, especially the Dean of the UHO Faculty of Medicine, Chair of the UHO LPPM.

\section{Bibliographic references}

1. La Ode Alifariki SK. Epidemiologi Hipertensi: Sebuah Tinjauan Berbasis Riset. Penerbit LeutikaPrio; 2019.

2. Alifariki LO. Analisis Faktor Determinan Proksi Kejadian Hipertensi di Poliklinik Interna BLUD RSU Provinsi Sulawesi Tenggara. Medula. 2015;3(1):214-23.

3. Sudayasa IP, Alifariki LO, Rahmawati, Hafizah I, Jamaludin, Milasari $\mathrm{N}$, et al. Determinant juvenile blood pressure factors in coastal areas of Sampara district in Southeast Sulawesi. Enferm Clin. 2020;

4. Ozkayar N, Dede F, Ates I, Akyel F, Yildirim T, Altun B. The relationship between dietary salt intake and ambulatory blood pressure variability in non-diabetic hypertensive patients. Nefrologia. 2016;36(6):694-700.

5. Elliott P, Stamler J, Nichols R, Dyer AR, Stamler R, Kesteloot H, et al. Intersalt revisited: further analyses of 24 hour sodium excretion and blood pressure within and across populations. Intersalt Cooperative Research Group. BMJ. 1996 May;312(7041):124953.
6. Tuomilehto J, Jousilahti P, Rastenyte D, Moltchanov V, Tanskanen $A$, Pietinen $P$, et al. Urinary sodium excretion and cardiovascular mortality in Finland: a prospective study. Lancet (London, England). 2001 Mar;357(9259):848-51.

7. Strazzullo P, Leclercq C. Sodium. Adv Nutr. 2014 Mar;5(2):18890.

8. Kimble et al. Applied Therapeutic The Clinical Use of Drugs, Ninth Edition. In: David B. Troy, editor. Ninth Edit. Philadelphia, Pennsylvania, USA: 5 Lippincott Williams \& Wilkins; 2009. p. 69-6, 69-13, 69-15, 69-16, 69-18, 69-29.

9. Nurpalah R RN. Gambaran Kadar Natrium (Na) pada pasien Hipertensi dengan rentang Usia 31-55 tahun. J Kesehat Bakti Tunas Husada. 2014;11(1).

10. Centers for Disease Control. The Role of Potassium and Sodium in Your Diet. Division for Heart Disease and Stroke Prevention; 2018.

11. Farquhar WB, Edwards DG, Jurkovitz CT, Weintraub WS. Dietary sodium and health: more than just blood pressure. J Am Coll Cardiol. 2015 Mar;65(10):1042-50.

12. Rivanli, Engka JNA, Sapulete IM. Hubungan kadar natrium dengan tekanan darah pada remaja. J e-Biomedik. 2016;4(2).

13. Joyner MJ, Casey DP. Regulation of increased blood flow (hyperemia) to muscles during exercise: a hierarchy of competing physiological needs. Physiol Rev. 2015 Apr;95(2):549-601.

14. Rafsanjani MS, Asriati A, Kholidha, Andi Noor AL. Hubungan Kadar High Density Lipoprotein (HDL) Dengan Kejadian Hipertensi. J Profesi Med J Kedokt dan Kesehat. 2019;13(2).

15. Frese EM, Fick A, Sadowsky HS. Blood pressure measurement guidelines for physical therapists. Cardiopulm Phys Ther J. 2011 Jun;22(2):5-12.

16. Magfirah AL. Pengaruh Terapi Berkebun Terhadap Perubahan Tekanan Darah Pada Lansia dengan Hipertensi di PSTW Minaula Kendari. J Islam Nurs. 2018;3(2):7-15.

17. Organization WH. Reducing salt intake in populations: report of a WHO forum and technical meeting, 5-7 October 2006, Paris, France. 2007;

18. Kemenkes RI, Kementerian Kesehatan RI. Profil Kesehatan Indonesia. Jakarta: Depkes Rl; 2018.

19. Bustam M. Epidemiologi Penyakit Tidak Menular. Jakarta: EGC; 2007.

20.Rampengan, Sukarno M. Perbandingan Tekanan Darah Antara Penduduk Yang Tinggal di Dataran Tinggi dan Dataran Rendah. J e biomedik. 2018:4(2):1-8.

21. Khomsan dkk, Baliwati, Y.F., Khomsan, A., Dwiriani CM 2004. Pengantar Pangan dan Gizi. Jakarta: Penebar Swadaya; 2004.

22. Falefi R dkk. Hubungan Konsumsi Makanan Laut Dengan Kejadian Hipertensi Pada Masyarakat Pesisir Di Wilayah Kerja Puskesmas Mangkang Kota Semarang. J Kesehat Masy. 2019;7(4):743-8.

23. Hamidah I. Studi Tentang Pola Konsumsi Masyarakat Pesisir Indramayu. J Biol Dan Pendidik Biol. 2017;1(2):46-51.

24. Ambard L. Causes de l'hypertension arterielle. Arch Gen Med. 1904:1:520-33.

25. Masengi S, Palar S, Rotty L. Pengaruh Konsumsi Makanan Laut Terhadap Kejadian Hipertensi Di Desa Malalayang Dua. J e-Biomedik. 2013;1(1):726-32.

26. Sundari dkk. Faktor Risiko Non Genetik dan Polimorfisme Promoter Region Gen CYP11B2 Varian T(-344)C Aldosterone Synthase pada Pasien Hipertensi Esensial di Wilayah Pantai dan Pegunungan. Universitas Brawijaya Malang; 2013.

27. Rusliafa J, Amiruddin R, Noor NB. Komparatif Kejadian Hipertensi Pada Wilayah Pesisir Pantai Dan Pegunungan Di Kota Kendari Tahun 2014. 2014

28. Fodor JG, Abbott EC, Rusted IE. An epidemiologic study of hypertension in Newfoundland. Can Med Assoc J. 1973;108(11):1365.

29. Page LB, Damon A, Moellering Jr RC. Antecedents of cardiovascular disease in six Solomon Islands societies. Circulation. 1974;49(6):1132-46.

Received: 12 December 2020

Accepted: 10 February 2021 